\title{
A double blind, randomised, multicentre comparison of two doses of intravenous iloprost in the treatment of Raynaud's phenomenon secondary to connective tissue diseases
}

Helen I Torley, Rajan Madhok, Hilary A Capell, R M L Brouwer, P J Maddison, C M Black, H Englert, J A Dormandy, H R Watson

\begin{abstract}
Objective-To compare low $(0.5 \mathrm{ng} / \mathrm{kg} / \mathrm{min})$ and standard dose $(2 \mathrm{ng} / \mathrm{kg} / \mathrm{min})$ iloprost (a stable carbacyclin analogue of prostacyclin) in patients with Raynaud's phenomenon secondary to connective tissue disorders.

Design-Double blind, random allocation, three six hour infusions on consecutive days. Follow up period eight weeks.

Setting-Rheumatology units, five teaching hospitals.

Patients-55 Patients with Raynaud's phenomenon (greater than seven attacks per week), 32 secondary to well documented classical progressive systemic sclerosis (American Rheumatism Association criteria), 11 CREST syndrome, 5 mixed connective tissue disease, 1 rheumatoid arthritis, 1 Sjögren's syndrome, 1 childhood dermatomyositis, and 4 abnormal nailfold capillaroscopy and antibody profiles but no definite diagnosis.
\end{abstract}

Interventions-All other treatment for Raynaud's phenomenon was discontinued two weeks before entry. 28 Patients were randomly allocated to receive the low dose, 27 the standard dose. Differing dilutions allowed infusion rates to be started at $10 \mathrm{ml} / \mathrm{h}$ with increments of $10 \mathrm{ml} / \mathrm{h}$ every 15 minutes until infusion rates reached $0.5 \mathrm{ng} / \mathrm{kg} / \mathrm{min}$ and $2 \mathrm{ng} / \mathrm{kg} / \mathrm{min}$ respectively.

Main outcome measure(s)-Reduction in frequency, duration, and severity of attacks of Raynaud's phenomenon. Assessment of ulcer and ischaemic lesion healing.

Results-Both dosage regimens were equally effective in reducing severity, frequency, and duration of Raynaud's attacks. Ulcer healing occurred to similar degree in both treatment groups (standard dose $44 \%$, low dose $39 \%$ ). Low dose was associated with significantly fewer side effects.

Conclusions-Both dosage regimens reduce severity of Raynaud's phenomenon and encourage ulcer healing. Low dose was associated with fewer side effects and was better tolerated by the patients.

Treatment of Raynaud's phenomenon secondary to connective tissue diseases remains a difficult problem for the doctor. ${ }^{1-5}$ Use of oral vasodilator drugs is limited by unpleasant side effects, such as headache, flushing, and ankle swelling, the inconvenience of frequent tablet ingestion, and in some cases by poor clinical response. Prostacyclin (prostaglandin $\mathrm{I}_{2}$ ) is a potent natural vasodilator, which has been shown to improve symptoms of Raynaud's phenomenon for up to six weeks after infusion. ${ }^{6}$ Its use, however, is limited by its chemical instability, short half life when reconstituted (12 hours), and dose limiting side effects secondary to vasodilatation.

Iloprost is a chemically stable carbacyclin derivative of prostacyclin, which has been shown in previous studies to have immediate and long term benefits in the treatment of Raynaud's phenomenon when compared with placebo $^{78}$ and to be as effective as nifedipine. The precise mechanism by which clinical benefit is produced is unclear. Iloprost produces vasodilatation, ${ }^{10}$ inhibition of platelet aggregation, ${ }^{11}$ and enhances inherent fibrinolytic potential, ${ }^{12} 13$ all of which may contribute to clinical benefit.

The current regimen for both drugs in the treatment of Raynaud's phenomenon is to increase the dose to the maximum tolerated by the patient. ${ }^{7}$ This, however, can result in unpleasant side effects-for example, nausea, headache, and flushing.

This study aimed at determining whether the efficacy of iloprost is dependent on dose within the range of doses being used clinically in secondary Raynaud's phenomenon and to establish whether longer term benefits are conferred independent of acute vasomotor effects.

\section{Patients and methods}

Fifty five patients were enrolled in the study from five centres (Glasgow (24), Rotterdam (12), West Middlesex, London (nine), Bath (eight), St James's Hospital, London (two)). All patients received their treatment between January 1988 and April 1988. Patients with Raynaud's phenomenon secondary to a connective tissue disease or with abnormal antibody profiles and nailfold capillaroscopy were eligible for entry. All patients had received no drugs for treatment of Raynaud's phenomenon for the two weeks before entry into the study and were experiencing at least seven Raynaud's attacks per week. Patients with known abnormal haemostasis, diabetes, vibration induced Raynaud's phenomenon, or hyperviscosity syndromes were excluded. Informed consent was given in each case and female patients of childbearing years advised about adequate contraception.

Of the 55 patients enrolled, 32 had classical progressive systemic sclerosis (American Rheumatism Association criteria), ${ }^{14} \quad 15 \quad 11$ 
limited cutaneous scleroderma, five mixed connective tissue disease, one rheumatoid arthritis, one Sjögren's syndrome, and one childhood dermatomyositis. In the remaining four patients no definite diagnosis had been established, but all had abnormal nailfold capillaroscopy and abnormal antibody profiles.

The study was double blind with patients being randomly allocated in parallel groups to the two treatment regimens. Twenty eight received low dose $(0.5 \mathrm{ng} / \mathrm{kg} / \mathrm{min})$ and 27 standard dose ( $2 \mathrm{ng} / \mathrm{kg} / \mathrm{min}$ ) iloprost. Investigators were unaware of the dose being used as different concentrations of iloprost were infused at the same rate. The mean age of the patients and their disease duration were similar in both groups (table 1).

During an initial two week assessment period a diary was kept recording the duration and severity of each Raynaud's attack. Thereafter, patients were admitted to the ward and received three six hour iloprost infusions on consecutive days. Iloprost was administered intravenously by a peripheral line and regulated by an IVAC pump. Both low and standard dose infusions were started at $10 \mathrm{ml} / \mathrm{h}$ and increased every 15 minutes until a maximum of $40 \mathrm{ml} / \mathrm{h}$ was reached. If adverse events occurred the infusion rate was reduced by $10 \mathrm{ml} / \mathrm{h}$ at 30 minute intervals until side effects settled. An observer was present during the infusion to record the occurrence of side effects.

Patients in the eight week follow up period recorded the frequency, duration, and severity (mild/moderate/severe) of Raynaud's attacks in their diaries.

\section{CLINICAL RESPONSE}

Assessment of clinical response was by diary analysis and digital ulcer count. Patients attended hospital at four and eight weeks after infusion, at which time an ulcer count was performed, any adverse events recorded, and the patients' subjective response sought. Patients were asked whether their Raynaud's phenomenon had definitely improved, probably improved, not changed, probably worsened, or definitely worsened.

\section{LABORATORY DATA}

Baseline white cell count, haemoglobin, platelet count, renal function and liver function tests were carried out on entry and repeated at week 8.

Table 1 Patient details

\begin{tabular}{|c|c|c|}
\hline & \multicolumn{2}{|l|}{ Iloprost } \\
\hline & $\begin{array}{l}L_{(n=28)} \\
\text { Low dose* }\end{array}$ & $\begin{array}{l}\text { Standard dose* } \\
(n=27)\end{array}$ \\
\hline $\begin{array}{l}\text { Age (years) } \\
\text { Mean } \\
\text { Range }\end{array}$ & $\begin{array}{l}47 \cdot 6 \\
(23-67)\end{array}$ & $\begin{array}{l}48 \cdot 8 \\
(25-77)\end{array}$ \\
\hline $\begin{array}{l}\text { Disease duration (years) } \\
\text { Mean } \\
\text { Range }\end{array}$ & $\begin{array}{l}11 \\
(2-30)\end{array}$ & $\begin{array}{l}14 \\
(1-70)\end{array}$ \\
\hline
\end{tabular}

STATISTICAL ANALYSIS

Demographic and baseline data were compared by Student's $t$ test. Skin lesions and Raynaud's attacks as recorded in the diaries were tested by split-plot analysis of variance (repeated measures) ${ }^{16}$ for treatment, time, and treatmenttime interaction effects using the $F$ test. Duncan's multiple range test was also used to determine where significant differences lay. Categorical data, such as the patients' assessment of improvement, were analysed by $\chi^{2}$ test.

\section{Results}

BASELINE DATA

Before treatment the mean frequency of Raynaud's attacks in the low dose group was 15.6 (SE 2.5) per week and in the standard dose group $17 \cdot 5(2 \cdot 4)$ per week. The total duration of Raynaud's attacks in minutes per week was 609 (142) low dose and 569 (120) standard dose. There were no significant differences between the two groups at the start of the study.

Fifty one patients completed the eight week follow up. Two patients withdrew owing to lack of effect, one from each treatment group, and two because of readmission to hospital for an operation, both from the standard dose group, one of whom underwent neck exploration for squamous carcinoma and one of whom required amputation of a necrotic digit. Of the remaining patients, all submitted diaries for the first four weeks and only three patients failed to submit diaries for weeks 5-8: one from the low dose group and two from the standard dose group.

\section{FOLLOW UP}

Analysis of diaries showed a significant reduction in frequency, severity, and duration of Raynaud's attacks in both treatment groups with no statistical differences between the two (table 2, figure 1).

Reduction of the frequency of Raynaud's attacks was greater in weeks 5-8 than $1-4$ $(p=0.016, F$ test). Reduction in severity of attacks was also greater in the second half of the follow up period $(p=0.03, F$ test $)$. The improvement seen during weeks 5-8 was unlikely to have been due to a rise in the ambient temperature as between weeks 1 and 4 there was no overall change in ambient temperature from baseline and between weeks 5 and 8 there was a small rise of less than $2^{\circ} \mathrm{C}$.

The results from the five centres taking part in this study were compared for duration of disease, total duration and frequency of attacks before treatment, and number of patients with skin lesions. No one centre had entered the most severely affected patients by every para-

Table 2 Percentage reduction in Raynaud's attacks after treatment with iloprost $0.5 \mathrm{ng} / \mathrm{kg} / \mathrm{min}$ (low dose) or $2 \mathrm{ng} / \mathrm{kg} / \mathrm{min}$ (standard dose)

\begin{tabular}{|c|c|c|c|c|}
\hline \multirow[t]{2}{*}{ Raymaud's attacks } & \multicolumn{2}{|c|}{ Low dose } & \multicolumn{2}{|c|}{ Standard dose } \\
\hline & Week 4 & Week 8 & Week 4 & Week 8 \\
\hline $\begin{array}{l}\text { Frequency } \\
\text { Duration (min) } \\
\text { Severity }\end{array}$ & $\begin{array}{l}25 \\
31 \\
16\end{array}$ & $\begin{array}{l}37 \\
46 \\
23\end{array}$ & $\begin{array}{r}24 \\
27 \\
4\end{array}$ & $\begin{array}{l}28 \\
20 \\
10\end{array}$ \\
\hline
\end{tabular}


Percentage reduction in frequency of Raynaud's attacks with $95 \%$ confidence intervals after treatment with iloprost $0.5 \mathrm{ng} / \mathrm{kg} / \mathrm{min}$ (low dose) or $2 \mathrm{ng} / \mathrm{kg} / \mathrm{min}$ (standard dose).

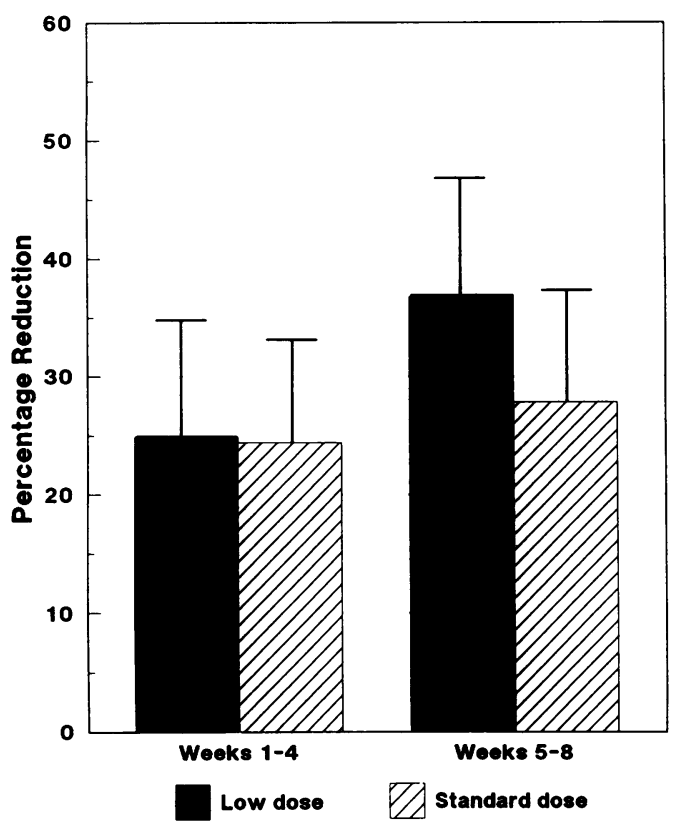

Table 3 Reduction in digital skin lesions after treatmen with iloprost $0.5 \mathrm{ng} / \mathrm{kg} / \mathrm{min}$ (low dose) or $2 \mathrm{ng} / \mathrm{kg} / \mathrm{min}$ (standard dose)

\begin{tabular}{llll}
\hline & $\begin{array}{l}\text { Number of } \\
\text { patients with } \\
\text { skin lesions }\end{array}$ & $\begin{array}{l}\text { Total number } \\
\text { of skin } \\
\text { lesions }\end{array}$ & \% Reduction \\
\hline Low dose & & 16 & \\
$\quad$ Before iloprost & 6 & 11 & \\
Week 4 & 4 & 9 & 44 \\
Week 8 & 5 & & \\
Standard dose & & 23 & \\
$\quad$ Before iloprost & 9 & 13 & 39 \\
Week 4 & 5 & 14 & \\
Week 8 & 5 & & \\
\hline
\end{tabular}

Table 4 Side effects occurring during infusions of iloprost $0.5 \mathrm{ng} / \mathrm{kg} / \mathrm{min}$ (low dose) or $2 \mathrm{ng} / \mathrm{kg} / \mathrm{min}$ (standard dose)

\begin{tabular}{llc}
\hline Side effects & $\begin{array}{l}\text { Low dose } \\
(n=28)\end{array}$ & $\begin{array}{l}\text { Standard dose } \\
(n=27)\end{array}$ \\
\hline Flushing & 3 & 3 \\
Headache & 8 & 20 \\
Nausea & 1 & 13 \\
Vomiting & 0 & 8 \\
Diarrhoea & 0 & 7 \\
Abdominal cramps & 0 & 6 \\
Painful eyes & 0 & 1 \\
Dizziness & 0 & 2 \\
Drowsiness & 1 & 0 \\
Tingling fingers & 1 & 3 \\
$\begin{array}{l}\text { Total number (\%) } \\
\text { of patients reporting } \\
\text { any side effect }\end{array}$ & & \\
\hline
\end{tabular}

meter and there is no reason to suggest that the result of the study was biased by the unequal recruitment of patients from the different centres.

\section{ULCER HEALING}

Eighteen patients had active digital skin lesions either on entry to the study or on follow up. Two patients with ulcers were withdrawn from the study owing to lack of effect (one from each treatment group). Both patients received additional treatment and are therefore excluded from analysis of treatment effect on skin lesions. There was a reduction in the total number of skin lesions in both treatment groups (table 3).
Table 5 Doses received by each treatment group after dose titration

\begin{tabular}{lll}
\hline $\begin{array}{l}\text { Actual dose infused } \\
(\mathrm{ng} / \mathrm{kg} / \mathrm{min})\end{array}$ & $\begin{array}{l}\text { Low dose } \\
(\mathrm{n}=28)\end{array}$ & $\begin{array}{l}\text { Standard dose } \\
(\mathrm{n}=27)\end{array}$ \\
\hline Mean & 0.54 & 1.95 \\
Range & $0.39-0.83$ & $0.67-2.96$ \\
\hline
\end{tabular}

Table 6 Changes in laboratory indices after infusion of iloprost $0.5 \mathrm{ng} / \mathrm{kg} / \mathrm{min}$ (low dose) or $2 \mathrm{ng} / \mathrm{kg} / \mathrm{min}$ standard dose)

\begin{tabular}{|c|c|c|c|c|}
\hline & \multicolumn{2}{|l|}{ Low dose } & \multicolumn{2}{|c|}{ Standard dose } \\
\hline & $\begin{array}{l}\text { Before } \\
\text { treatment }\end{array}$ & Week 8 & $\begin{array}{l}\text { Before } \\
\text { treatment }\end{array}$ & Week 8 \\
\hline $\begin{array}{l}\text { Haemoglobin }(\mathrm{g} / \mathrm{l}) \\
\text { Number } \\
\text { Mean } \\
\text { SE }\end{array}$ & $\begin{array}{r}28 \\
122 \cdot 4 \\
4 \cdot 5\end{array}$ & $\begin{array}{r}27 \\
120 \cdot 0 \\
4 \cdot 6\end{array}$ & $\begin{array}{r}27 \\
121 \cdot 3 \\
4 \cdot 9\end{array}$ & $\begin{array}{r}27 \\
121 \cdot 1 \\
4 \cdot 7\end{array}$ \\
\hline $\begin{array}{l}\text { Platelets }\left(\times 10^{9} / 1\right) \\
\text { Number } \\
\text { Mean } \\
\text { SE }\end{array}$ & $\begin{array}{r}28 \\
285 \cdot 18 \\
14 \cdot 49\end{array}$ & $\begin{array}{c}25 \\
294 \cdot 72^{*} \\
16 \cdot 22\end{array}$ & $\begin{array}{l}26 \\
287 \cdot 19 \\
18 \cdot 71\end{array}$ & $\begin{array}{c}25 \\
318 \cdot 00^{*} \\
19 \cdot 02\end{array}$ \\
\hline $\begin{array}{l}\text { White cell count } \\
\left(\times 10^{9} / 1\right) \\
\text { Number } \\
\text { Mean } \\
\text { SE }\end{array}$ & $\begin{array}{l}28 \\
6 \cdot 75 \\
0 \cdot 39\end{array}$ & $\begin{array}{l}25 \\
7 \cdot 43 \dagger \\
0.46\end{array}$ & $\begin{array}{r}27 \\
6.66 \\
0.40\end{array}$ & $\begin{array}{l}25 \\
7 \cdot 74 t \\
0.54\end{array}$ \\
\hline
\end{tabular}

${ }^{*} \mathrm{p}=0.02$ (paired $t$ test). Significant increase both groups.

${ }_{0}^{*} \mathrm{p}=0.02$ (paired $t$ test). Significant increase both groups.
$t \mathrm{p}=0.0018$ (paired $t$ test). Significant increase both groups.

Six new lesions occurred in the low dose group compared with three in the standard group.

PATIENTS' SUBJECTIVE OPINIONS

At weeks 4 and 8 after infusion patients were asked whether they thought they had benefited from treatment. Thirty three patients $(60 \%)$ thought that they had probably or definitely improved at week 4 and $29(53 \%)$ at week 8 . More patients receiving the low dose (19/28 $(68 \%))$ thought they had derived benefit compared with those receiving the standard dose $(11 / 27(41 \%))$, though this did not reach significance $\left(p=0.07, \chi^{2}\right.$ test).

\section{SIDE EFFECTS AND DOSE INFUSED}

Side effects were reported in nine (32\%) patients receiving the low dose compared with $21(78 \%)$ patients in the standard dose group $(p=0.0013$, $\chi^{2}$ test). Table 4 shows the side effects reported.

Adverse events severe enough to require a reduction in dose occurred in one patient $(4 \%)$ in the low dose group and in $16(59 \%)$ patients in the standard dose group ( $\mathrm{p}<0.001, \chi^{2}$ test). The dose reductions did not seriously compromise the comparison of the two dose regimens in this study, however. As shown in table 5 the mean doses given to the patients were close to those planned and although the ranges overlapped, only one patient in the standard dose group received less than $1 \cdot 25$ $\mathrm{ng} / \mathrm{kg} / \mathrm{min}$.

Concurrent drugs for the relief of side effects were given to four (14\%) of the low dose group and $16(59 \%)$ of the standard dose group (metoclopramide or paracetamol).

Blood samples taken before treatment and again 
at the end of the study showed no differences between the two treatment groups at either time point for any of the haematological or biochemical indices (table 6). A comparison of the change at week 8 from values before treatment also failed to show any difference between the two dosage regimens. Analysis of change at week 8 from values before treatment, irrespective of dose given, showed a mean increase in platelet count of 5.9 (SE 2.4$) \%(p=0.02$, paired $t$ test) and a mean increase in white cell count of $13.3(4 \cdot 9) \% \quad(p=0 \cdot 0018$, paired $t$ test).

\section{Discussion}

Many factors are thought to contribute to the development of Raynaud's phenomenon in patients with connective tissue diseases. Vasospasm, increased sympathetic tone, local sensitivity to cold, and immune complex deposition are all thought to play a part. ${ }^{17}$ At a cellular level in secondary Raynaud's phenomenon several abnormalities have been shown. Belch $e t$ al found evidence of disordered fibrinolysis with reduced plasminogen activator activity as a consequence of endothelial cell damage. ${ }^{18} 19$ In addition, increased plasma viscosity, reduced red cell deformability, increased platelet aggregation, and raised concentrations of $\beta$ thromboglobulin were found, all of which may play a part in reduced microvascular blood flow and thrombosis.

Prostaglandin $\mathrm{E}_{1}{ }^{20}$ and prostacyclin (epoprostenol ${ }^{1962122}$ given by intravenous infusion have been shown to produce improvement in patients with secondary Raynaud's phenomenon with a reduction in the severity and frequency of attacks which was maintained for up to six weeks after the infusion. Use of prostaglandin $E_{1}$ is limited, however, as it has to be given through a central line because of thrombophlebitis.

Prostacyclin and its chemically stable carbacyclin derivative iloprost ${ }^{24}$ have been extensively studied. Both have been shown to inhibit platelet aggregation, ${ }^{11} 25$ enhance fibrinolysis, ${ }^{12} 13$ increase red cell deformability, ${ }^{23}$ and reduce white cell adhesion to endothelial cells. $^{24} 26$ The relative potency of iloprost compares favourably with prostacyclin in vitro, and, in particular, iloprost can be shown to be both qualitatively and quantitatively more effective as an inhibitor of platelet aggregation than prostaglandin $E_{1}$ and prostacyclin. Iloprost inhibits platelet aggregation by increasing intracellular levels of CAMP. ${ }^{25}$ It has been shown to be particularly effective against thrombin induced platelet activation, which may be important in connective tissue disorders such as scleroderma.

In our study we were interested to confirm that the benefits of iloprost in secondary Raynaud's phenomenon are only in part dependent on an acute vasodilator effect. We showed that by using a low dose, side effects are reduced and the improved ulcer healing and reduction in Raynaud's phenomenon are similar in magnitude and duration to those produced by the standard dose.
The increase in platelet count seen in this study has previously been reported ${ }^{27}$ with CL115, 347 a transdermally absorbed prostaglandin $E_{2}$ analogue, and may reflect decreased platelet activation over the treatment period. The increase in white cell count has not previously been reported, as far as we know, and may simply be a result of decreased white cell adhesion or a shift from a marginated pool to a circulating pool.

In conclusion, we showed that iloprost given in low dose $0.5 \mathrm{ng} / \mathrm{kg} / \mathrm{min}$ is an effective treatment for Raynaud's phenomenon and its use is associated with significantly fewer side effects than the standard dose. Furthermore, we showed that both standard and low dose iloprost enhance ulcer healing. These findings therefore suggest that vasodilatation alone has only a small part to play in the mechanism by which iloprost improves Raynaud's phenomenon and certainly cannot explain the sustained improvement seen. In support of this, Rademaker et al demonstrated long term improvements in digital microcirculation with iloprost, ${ }^{9}$ which in view of its short half life could not have been due to vasodilatation alone. Enhancement of fibrinolysis, inhibition of platelet aggregation, and reduced white cell aggregation may each play a part.

We thank Schering Health Care for their financial support and Miss A Tierney who typed the manuscript.

1 Smith C D, McKendry R J R. Controlled trial of nifedipine in the treatment of Raynaud's phenomenon. Lancet 1982; ii: t299-301.

2 Kahan A. Nifedipine in the treatment of Raynaud's syndrome. Ann Intern Med 1981; 94: 546.

3 Siebald J R, Jageneau A H M. Treatment of Raynaud's phenomenon with ketanserin, a selective antagonist of the serotonin $_{2}\left(5 \mathrm{HT}_{2}\right)$ receptor. Arthritis Rheum 1984; 27: $139-46$.

4 Jarrett P E M, Merland M, Browse N L. Treatment of Raynaud's phenomenon by fibrinolytic enhancement. $B M \mathcal{F}$ 1978; ii: 523-5.

5 Holt G. An experimentally controlled evaluation of the effect of inositol nicotinate upon the digital blood flow in patients with Raynaud's phenomenon. 7 Int Med Res 1979; 7 473-83.

6 Belch J J F, Drury J K, Capell H A, et al. Intermittent epoprostenol (prostacyclin) infusion in patients with Raynaud's syndrome. Lancet 1983; i: 313-7.

7 Yardumian D A, Isenberg D A, Rustin M, et al. Successful treatment of Raynaud's syndrome with iloprost, a chemically
stable prostacyclin analogue. $B r \mathcal{F}$ Reumatol 1988; 27: 220-6.

8 McHugh N J, Csuka M, Watson H R, et al. Infusion of iloprost, a prostacyclin analogue, for treatment of Raynaud's phenomenon in systemic sclerosis. Ann Rheum Dis 1988 47: 43-7.

9 Rademaker M, Cooke E D, Almond N E, et al. Comparison of intravenous infusions of iloprost and oral nifedipine in treatment of Raynaud's phenomenon in patients with systemic sclerosis: a double blind randomised study. $B M \mathcal{F}$ 1989; 298: $561-4$.

10 Rademaker M, Thomas R H M, Provost G, Beacham J A, Cooke E D, Kirby J D. Prolonged increase in digital blood flow following iloprost infusion in patients with systemic flow following iloprost infusion in patients

11 Fisher C A, Kappa J R, Sinha A K, Cottrell E D, Reiser H J, Addonizio V P. Comparison of equimolar concentrations of iloprost, prostacyclin and prostaglandin $E_{1}$ on human platelet function. F Lab Clin Med 1987; 109: 184-90.

12 Musial J, Wilczynska M, Sladek K, Cierniawski C S Nizankowski R, Szczeklik A. Fibrinolytic activity of prostacyclin and iloprost in patients with peripheral arteria disease. Prostaglandins 1986; 31: 61-70.

13 Bertele V, Mussoni L, del Rosso G, et al. Defective fibrinolytic response in atherosclerotic patients - effect of iloprost and its possible mechanism of action. Thromb Haemost 1988; 60: $141-4$.

14 Masi A, Rodnan G, Medsger T A, et al. Preliminary criteria for the classification of systemic sclerosis (scleroderma) Arthritis Rheum 1980; 23: 581-90.

15 Steen V D, Ziegler G L, Rodnan G P, Medsger T A Jr. Clinical and laboratory association of anticentromere antibody in patients with progressive systemic sclerosis. Arthritis Rheum 1984; 27: 125-31. 
16 Evans $\mathrm{S} \mathrm{J} \mathrm{W}$. Uses and abuses of analysis of variance. $\mathrm{Br} \mathcal{J}$ Clin Pharmacol 1983; 15: 629-48.

17 Kahaleh M B, Lekey E C. Scleroderma (systemic sclerosis): treatment and clinical manifestations as related to pathogenesis. In: Cohen A S, ed. Progress in clinical rheumatology. Vol 1. New York: Grune and Surattin 1994

18 Belch J J F, Drury J, McLaughlin K, et al. Abnormal biochemical and cellular parameters in the blood of patients with Raynaud's phenomenon. Scott Med $\mathcal{J}$ 1987; 32: 12-14

19 Belch J J F, McLaren M, Anderson J, et al. Increased prostacyclin metabolites and decreased red cell deformability in patients with systemic sclerosis and Raynaud's syndrome. Prostaglandins Leukot Med 1985; 17: $1-9$.

20 Kyle V, Parr G, Salisbury R, Thomas P P, Hazleman B. Prostaglandin $\mathbf{E}_{1}$, vasospastic disease and thermography. Ann Rheum Dis 1985; 44: 73-8.

21 Belch J J F, Newman P, Drury J K, et al. Successful treatment of Raynaud's syndrome with prostacyclin. treatment of Raynaud's syndromb

22 Dowd P M, Martin M F R, Cooke E D, et al. Treatment of Raynaud's phenomenon by intravenous infusion of prostacyclin $\left(\mathrm{PGI}_{2}\right)$. Br $\mathcal{F}$ Dermatol 1982; 106: 81-9.
23 Dowd P M, Kovacs I B, Bland C J H, Kirby J D T. Effect of prostaglandias $I_{2}$ and $E_{1}$ on red cell deformability in patients with Raynaud 1981; 283: 350.

24 Skuballa W, Raduchel B, Vorbruggen H. Chemistry of stable prostacyclin analogues: synthesis of iloprost. In: Gryglewski R J, Stock G, eds. Prostacyclin and its stable analogue
iloprost. Berlin, Heidelberg: Springer, 1987: 17-24.

25 Boxer L A, Allen J M, Schmidt M, Toder M, Bachner R L. Inhibition of polymorphonuclear leukocyte adherence by prostacyclin. f Lab Clin Med 1980; 95: 672-8.

26 Belch J J F, Saniabadi A, Dickson R, Sturrock R D, Forbes $C D$. Effect of iloprost ZK 36374 on white cell behaviour. In: Gryglewski R J, Stock G, eds. Prostacyclin and its stable analogue iloprost. Berlin, Heidelberg: Springer, 1987: 97-102.

27 Belch J J F, Shaw B, Madhok R, Leiberman D P, Sturrock R D, Forbes C D. Double-blind trial of CL115, 347, a transdermally absorbed prostaglandin $E_{2}$ analogue in the treatment of Raynaud's phenomenon. Lancet 1985; i: 1180-3. 